\title{
Article
}

\section{Systematic review of interventions to encourage careers in academic medicine}

Darbyshire, Daniel, Gordon, Morris, Agius, Steven and McAleer, Sean

Available at http://clok.uclan.ac.uk/21791/

Darbyshire, Daniel, Gordon, Morris ORCID: 0000-0002-1216-5158, Agius, Steven and McAleer, Sean (2018) Systematic review of interventions to encourage careers in academic medicine. Medical Teacher. ISSN 0142-159X

It is advisable to refer to the publisher's version if you intend to cite from the work. http://dx.doi.org/10.1080/0142159x.2018.1438590

For more information about UCLan's research in this area go to

http://www.uclan.ac.uk/researchgroups/ and search for < name of research Group>.

For information about Research generally at UCLan please go to http://www.uclan.ac.uk/research/

All outputs in CLoK are protected by Intellectual Property Rights law, including Copyright law. Copyright, IPR and Moral Rights for the works on this site are retained by the individual authors and/or other copyright owners. Terms and conditions for use of this material are defined in the policies page. 
Title Page

i) The title of the paper

\section{Systematic review of interventions to encourage careers in academic medicine}

ii) A short title not exceeding 45 characters for use as a running head

Encouraging academic careers

iii) Names of authors

Daniel Darbyshire, Morris Gordon, Paul Baker, Steven Agius, Sean McAleer

iv) Names of the institutions at which the research was conducted

Centre for Medical Education, University of Dundee, UK.

Health Education England (North West), Manchester, UK.

v) Name, address, telephone and fax number, and email address of corresponding author.

Daniel Darbyshire

Emergency Department, Blackpool Victoria Hospital, Blackpool, UK.

dsdarbyshire@doctors.org.uk

(+44) 1253300000 